VNU Journal of Science: Legal Studies Journal homepage: https://js.vnu.edu.vn/LS

\title{
Review Article \\ Modern International Law of the Sea: Role, Challenges and Proposals
}

\author{
Nguyen Ba Dien* \\ VNU School of Law, 144 Xuan Thuy, Cau Giay, Ha Noi, Viet Nam
}

Received 15 January 2021

Revised 20 February 2021; Accepted 25 March 2021

\begin{abstract}
Following the tendency of "moving forward to the sea, controlling the sea", together with the development of science, technology, the birth of the 1982 United Nations Convention on the Law of the Sea (UNCLOS 1982) marked an important turning point in the history of development of the Modern International Law of the Sea. As a textual, multilateral legal document, consisting of 320 articles and 09 Appendices, with more than 1000 legal principles, the UNCLOS 1982 is considered as a "constitution on the sea and ocean for mankind". This paper clearly focuses on the basic problems of the UNCLOS 1982, reviews the major contribution of this convention to the development process of International Law as well as the process of being an useful tool for sea and ocean governance in peace, creating an effective dispute settlement mechanism. In addition, the paper also states challenges from the climate change, environmental security, and sovereign claims of countries to the UNCLOS 1982 and the modern International Law of the Sea, on that basis, points out issues that need to be considered, amended and supplemented in order to complement the UNCLOS 1982.
\end{abstract}

Keywords: Convention on the Law of the Sea, UNCLOS 1982, sea and island sovereignty, challenge, role, dispute settlement mechanism, International Law of the Sea.

\footnotetext{
* Corresponding author.

E-mail address: nbadien@yahoo.com.vn

https://doi.org/10.25073/2588-1167/vnuls.4350
} 


\title{
Luật biển Quốc tế hiện đại: Vai trò, thách thức và khuyến nghị
}

\author{
Nguyễn Bá Diến* \\ Khoa Luật, Đại học Quốc gia Hà Nội, 144 Xuân Thủy, Cầu Giấy, Hà Nội, Việt Nam \\ Nhận ngày 15 tháng 01 năm 2021 \\ Chỉnh sửa ngày 20 tháng 02 năm 2021; Chấp nhận đăng ngày 25 tháng 3 năm 2021
}

\begin{abstract}
Tóm tắt: Hòa chung với xu thế "tiến ra biển, làm chủ biển" cũng như sự phát triển của khoa học, công nghệ, sự ra đời của Công ước của Liên Hợp quốc về Luật Biển năm 1982 (UNCLOS 1982) đã đánh dấu một bước ngoặt quan trọng trong lịch sử phát triển của Luật Biển Quốc tế hiện đại. Là một văn kiện pháp lý đa phương đồ sộ, bao gồm 320 điều khoản và 9 Phụ lục, với hơn 1000 quy phạm pháp luật, UNCLOS 1982 được coi là "hiến pháp về biển và đại dương của nhân loại". Bài viết tập trung nêu rõ những vấn đề cơ bản của UNCLOS 1982, đánh giá những đóng góp to lớn của Công ước này đối với quá trình phát triển của Luật Quốc tế cũng như quá trình là công cụ hữu hiệu quản trị biển và đại dương một cách hòa bình, tạo ra một cơ chế giải quyết tranh chấp biển đảo hiệu quả. Ngoài ra, bài viết còn nêu những thách thức từ biến đối khí hậu, an ninh môi trường, yêu sách chủ quyền của các nước đối với UNCLOS 1982 và Luật Biển Quốc tế hiện đại, trên cơ sở đó, đề xuất các vấn đề cần xem xét, sửa đổi, bổ sung nhằm hoàn thiện UNCLOS 1982.
\end{abstract}

Từ khóa: Công ước Luật biển, UNCLOS 1982, chủ quyền biển đảo, thách thức, vai trò, cơ chế giải quyết tranh chấp, Luật biển Quốc tế.

Luật biển Quốc tế là một chế định (một ngành hay một nhánh) của Luật Quốc tế. Vì vậy, Luật Biển Quốc tế có lịch sử phát triển lâu đời ngang với Luật Quốc tế. Luật Biển bắt đầu xuất hiện từ khi các quốc gia thực hiện quyền chủ quyền và tiến hành các hoạt động của mình trên biển. Sự phát triển đó được thúc đẩy bởi các yếu tố chính trị, quốc phòng, an ninh, kinh tế-thương mại; và trong thời gian gần đây là các lợi ích về khoa học, môi trường. Những tiến bộ vượt bậc trong lĩnh vực khoa học- công nghệ cũng đóng góp một vai trò quan trọng trong sự phát triển của Luật Biển Quốc tế. Việc con người phát minh ra các phương pháp bảo quản cá (ướp muối và sau đó là đông lạnh); những tiến bộ vượt bậc trong công nghệ khoan đáy biển, việc phát hiện ra các khối đa kim

\footnotetext{
*Tác giả liên hệ.

Địa chỉ email: nbadien@yahoo.com.vn

https://doi.org/10.25073/2588-1167/vnuls.4350
}

(polymetallic nodules- quặng là hỗn hợp của nhiều kim loại) dưới đáy biển sâu,v.v... là nguyên nhân sâu xa của dẫn đến việc xây dựng các quy phạm pháp luật quốc tế cho các khu vực biển và đại dương và các hoạt động chưa được kiểm soát trước đây. Sự phát triển của khoa học kỹ thuật cùng những lợi ích mà biển mang lại đã làm gia tăng các yêu sách trên biển cũng như về việc thực hiện các đặc quyền của quốc gia (chủ quyền và quyền tài phán) [1] lại thêm những động lực cho những bước phát triển của Luật Biển Quốc tế trong những năm qua.

Cho đến cuối thế kỷ XIX, Luật Biển Quốc tế chủ yếu bao gồm các tập quán quốc tế; từ các tuyên bố của Hoa Kỳ về việc thực hiện các đặc quyền đối với một phần của biển và phản ứng của các quốc gia khác với các tuyên bố đó ${ }^{1}$.

\footnotetext{
${ }^{1}$ Sau Tuyên bố của Tổng thống Truman ngày 28/09/1945 về việc mở rộng thềm lục địa của Hoa Kỳ và yêu cầu việc phân định thềm lục địa phải trên cơ sở nguyên tắc công bằng, một loạt các nước khác
} 
Sau đó, các quy phạm Luật Biển được hình thành theo nhiều cách khác nhau. Cộng đồng quốc tế đã nỗ lực xây dựng Luật Biển Quốc tế trong khoảng gần thế kỷ trở lại đây. Chỉ trong vòng chưa đầy năm mươi năm, đã có đến bốn hội nghị quốc tế mang tính toàn cầu về Luật Biển do Hội quốc liên và Liên hợp quốc tổ chức: Hội nghị Hague năm 1930, Hội nghi Geneva năm 1958², Hội nghị Geneva năm 1960 và Hội nghị quốc tế về Luật Biển lần thứ III (UNCLOS III) kết thúc vào năm 1982 với sự thông qua Công ước của Liên hợp quốc về Luật Biển (UNCLOS 1982) hiện đang có hiệu lực đối với 168 quốc gia. Đồng thời, nhiều điề̀u ước về những vấn đề cụ thể khác đã được ký kết: các hiệp định về phân định biển, hiệp định về hợp tác cùng phát triển, đặc biệt là về đánh cá và bảo vệ môi trường biển,...

\section{Công ước Luật Biển của Liên Hợp quốc năm 1982}

Trong số hàng loạt các văn bản pháp lý quốc tế đã được ban hành, thì Công ước Liên hợp Quốc về Luật Biển năm 1982 (UNCLOS 1982) vẫn được coi là văn bản trụ cột, là "hiến pháp của đại dương", là một trong những thành tựu có ý nghĩa nhất trong lĩnh vực luật quốc tế của nhân loại trong thế kỷ XX và thực sự là nòng cốt của Luật Biển Quốc tế hiện đại ${ }^{3}[2]$.

cũng ra tuyên bố vê thềm lục địa, như: $\mathrm{Cu} B \mathrm{Ba}$ (1945), Mêhico (1945, 1949), Achentina (1946); Chile, Ecuado, Peru (1947), Côxta Rica (1948), Irac, Arap Xeut), Barain, Cô Oet, Quatar(1949), Braxin (1950),...

${ }^{2}$ Hội nghị có 86 nước tham dự và đã thông qua được 4 công ước đầu tiên về Luật Biển: 1) Công ước về Lãnh hải và Vùng tiếp giáp (có hiệu lực 10/9/1964); 2) Công ước về Thềm luc địa (có hiệu lực 10/6/1964); Công ước về Biển cả (hiệu lực $30 / 9 / 1962)$; 4) Công ước về Đánh cá và Bảo vệ tài nguyên sinh vật biển (có hiệu lực 20/3/1966). Những Công ước này, bước đầu đã ghi nhận chế độ pháp lý của các vùng biển và những nguyên tắc căn bản nhất của Luật Biển: nguyên tắc tôn trọng chủ quyền quốc gia ven biển và nguyên tắc tự do biển cả.

${ }^{3}$ Sau khoảng 5 năm chuẩn bị và 9 năm đàm phán, ngày 10/12/1982, UNCLOS 1982 được 157 quốc
Sau Hiến chương Liên Hợp quốc, UNCLOS 1982 được đánh giá là văn kiện pháp lý quốc tế quan trọng nhất kể từ sau chiến tranh thế giới thứ hai. Là một điều ước quốc tế đa phương đồ sộ, tổng hợp và toàn diện, độc nhất vô nhị (cho đến thời điểm hiện nay), với 320 điều khoản, 17 phần và 9 phụ lục, trên 1000 quy phạm pháp luật và các văn bản tiếp theo như Thoả thuận thực hiện phần XI của UNCLOS 1982 (Thoả thuận 1994), Thỏa thuận về Đàn cá di cư của Liên hợp quốc năm 1995 (Thỏa thuận 1995), đã đưa ra tổng thể hệ thống quy phạm bao trùm tất cả các vấn đề quan trọng nhất, từ chế độ pháp lý của các vùng biển và đại dương thế giới, cho đến những quyền và nghĩa vụ về nhiều mặt của mọi quốc gia (có biển cũng như không có biển, có chế độ chính trị, kinh tế khác nhau, có trình độ phát triển khác nhau) đối với các vùng biển thuộc quyền tài phán quốc gia cũng như đối với vùng biển quốc tế, bao gồm cả đáy biển và lòng đất dưới đáy biển nằm ngoài quyền tài phán quốc gia [3]. UNCLOS 1982 đã thiết lập một chế độ thực sự toàn diện cho Luật Biển, tái khẳng định các lĩnh vực pháp luật đã được giải quyết, đồng thời mở rộng sự phát triển trong các lĩnh vực khác, và trong một số trường hợp hoàn toàn tạo ra pháp luật quốc tế mới [ $[4$, tr.12]. Mặc dù UNCLOS được chấp nhận rồng rãi, nhưng cho đến nay vẫn còn một số quốc gia chưa tham gia Công ước, trong đó có 14 quốc gia ven biển chưa là thành viên của UNCLOS $1982^{4}$.

gia, trong đó có Việt Nam, ký tại Montego Bay Jamaica, đánh dấu thành công của Hội nghị Liên Hợp Quốc về Luật Biển lần thứ 3, với sự tham gia của trên 150 quốc gia và nhiều tổ chức quốc tế, kể cả các tổ chức quốc tế phi chính phủ, cùng xây dựng nên một Công ước mới về Luật Biển, được nhiều quốc gia, kể cả những quốc gia không có biển, cùng chấp nhận. UNCLOS 1982 có hiệu lực từ ngày $16 / 11 / 1994$. Tính đến ngày 31/12/2020, UNCLOS có 168 quốc gia đã phê chuẩn, 14 quốc gia đã ký kết nhưng chưa phê chuẩn, 41 quốc gia ra tuyên bố loại trừ thẩm quyền của các cơ chế tài phán theo Điều 298 UNCLOS 1982.

${ }^{4}$ Cambodia, Colombia, El Salvador, Eritrea, Iran, Israel, Bắc Triều Tiên, Peru, Syria, Thổ Nhĩ Kỳ, Các tiểu vương quốc Ả Rập, Mỹ và Venezuela. 
Với 17 Phần, 9 Phụ lục và 02 Thỏa thuận bổ sung (Thỏa thuận năm 1994 và Thỏa thuận năm 1995), UNCLOS 1982 đã điều chỉnh một cách toàn diện hoạt động khai thác, sử dụng và quản lý của mọi quốc gia trên các vùng biển và đại dương. Phần I chỉ bao gồm Điều 1 và chủ yếu chứa các điều khoản định nghĩa. Chế độ pháp lý của lãnh hải và vùng tiếp giáp được quy định trong Phần $\mathrm{II}$, với sự kế thừa Công ước Geneva năm 1958 về Lãnh hải và Vùng tiếp giáp, có một số bổ sung đáng kể: bề rộng của lãnh hải không vượt quá 12 hải lý tính từ các đường cơ sở trên lãnh hải và vùng tiếp giáp không được phép mở rộng quá 24 hải lý tính từ đường cơ sở. Quyền đi qua không gây hại trong lãnh hải vẫn được mở ra cho tàu thuyền nước ngoài và với những quy tắc và điều kiện cần thiết ${ }^{5}$.

Vấn đề quá cảnh qua eo biển quốc tế được ghi nhận tại Phần III UNCLOS 1982, tạo ra một chế độ mới: chế độ pháp lý của các vùng nước các eo biển dùng cho hàng hải quốc tế; quyền và nghĩa vụ của tàu thuyền và phương tiện bay trong khi quá cảnh; luật lệ và nghĩa vụ của quốc gia ven eo biển .

Về các quốc gia quần đảo, đã được quy định khá chi tiết tại Phần IV UNCLOS 1982 với những nội dung quan trọng như: Định nghĩa "Quần đảo" và "Quốc gia quần đảo"; đường cơ sở quần đảo; chế độ pháp lý và việc hoạch định các vùng nước quần đảo, lãnh hải, vùng tiếp giáp lãnh hải, vùng đặc quyền kinh tế và thềm lục địa của quần đảo; quyền đi qua không gây hại của tàu thuyền mọi quốc gia và quyền đánh bắt hải sản truyền thống của các quốc gia kế cận và quyền được tôn trọng các dây cáp ngầm hiện có của các quốc gia khác; các nghĩa vụ cuả tàu thuyền và phương tiện bay trong khi đi qua cũng như nghĩa vụ của quốc gia quần đảo.

\footnotetext{
${ }^{5}$ Quy tắc áp dụng cho tất cả các loại tàu thuyền (Tiểu mục A, Mục 3, Phần II, UNCLOS 1982); Quy tắc áp dụng cho tàu buôn và tàu nhà nước dùng vào mục đích thương mại (Tiểu mục $\mathrm{B}$, Mục 3, Phần II UNCLOS 1982); Quy tắc áp dụng cho các tàu chiến và các tàu thuyền khác của nhà nước được dùng vào những mục đích không thương mại (Tiểu mục $\mathrm{C}$, Mục 3, Phần II UNCLOS 1982)
}

Chế độ pháp lý của các vùng biển thuộc quyền chủ quyền quốc gia (vùng EEZ và Thềm lục địa) cũng được ghi nhận trong Phần $\mathrm{V}$ và $\mathrm{VI}$ của UNCLOS 1982, theo đó, cho phép các quốc gia ven biển có quyền chủ quyền và nghĩa vụ nhất định đối với tài nguyên lên đến 200 hải lý trong ở vùng $\mathrm{EEZ}$ và Thềm lục địa (tối thiểu 200 hải lý hoặc tối đa 350 hải lý tính từ đường cơ sở hoặc cách đường đẳng sâu 2500 mét một khoảng cách 100 hải lý). Cùng với việc xác định quyền và nghĩa vụ của quốc gia ven bờ ở EEZ và Thềm lục địa, UNCLOS 1982 còn ghi nhận các quyền và nghĩa vụ của các quốc gia khác ở các vùng biển này.

Chế độ biển cả được trình bày trong Phần VII UNCLOS 1982 (phần lớn kế thừa từ Công ước Geneva năm 1958 về Biển cả), với việc ghi nhận các quyền tự do biển cả, bao gồm quyền tự do hàng hải, tự do hàng không, tự do đặt dây cáp và ống dẫn ngầm, tự do xây dựng đảo nhân tạo và các kết cấu khác, tự do đánh bắt hải sản và quyền tiến hành nghiên cứu khoa học ${ }^{6}$. Đồng thời, Phần VII UNCLOS 1982 còn quy định về tính bất hợp pháp về những yêu sách về chủ quyền đối với biển cả, về quốc tịch của tàu thuyền, về nghĩa vụ của quốc gia đối với tàu thuyền mang cờ; về quyền tài phán hình sự đối với tai nạn đâm va; về chuyên chở nô lệ; về cướp biển và buôn bán ma túy, về phát sóng không được phép từ biển cả; quyền truy đuổi; việc bảo tồn và quản lý các tài nguyên sinh vật của biển cả,...

Các phần từ phần VIII đến X UNCLOS 1982 quy định về một loạt các trường hợp đặc biệt. Phần VIII bao gồm Điều 121 đề cập đến chế độ các đảo (định nghĩa về đảo, các điều kiện để một đảo có lãnh hải, vùng tiếp giáp, vùng đặc quyền kinh tế và thềm lục địa). Phần IX đề cập đến các vùng biển kín hoặc nửa kín, bao gồm việc đưa ra một định nghĩa cho biển kín hay nửa kín và việc định ra các cơ chế hợp tác giữa các quốc gia ven biển kín hay nửa kín. Phần $\mathrm{X}$ quy định những quyền hạn nhất định của các quốc gia không có biển trong việc đi ra biển và từ biển vào (quyền tự do quá cảnh, miễn trừ thuế quan và lệ phí, việc đối xử bình

$\overline{{ }^{6} U N C L O S} 1982$, Điều 87(1). 
đẳng giữa các tàu mang cờ của quốc gia không có biển với các tàu nước ngoài khác,...).

Phần XI UNCLOS 1982 đề cập đến chế độ đáy biển và lòng đất dưới đáy biển nằm bên ngoài các vùng biển thuộc quyền tài phán quốc gia (Vùng) và là một trong những phần dài nhất và chi tiết nhất của UNCLOS $1982^{7}$. Chế độ pháp lý của Vùng đáy biển nằm ngoài các vùng biển thuộc quyền tài phán quốc gia, được Công ước ghi nhận là "Vùng" (The Area), là đối tượng đặc biệt với chế độ pháp lý dựa trên nguyên tắc di sản chung của nhân loại. ${ }^{8}$ Theo Phần XI, một cơ quan về đáy biển quốc tế được gọi là Cơ quan quyền lực chung có chức năng giám sát các hoạt động diễn ra ở Vùng, trong khi một cơ quan khác, "Doanh nghiệp", có chức năng thực hiện việc thăm dò và khai thác đáy biển sâu phù hợp với các nguyên tắc di sản chung. Một đặc điểm đặc trưng của Phần XI là các điều khoản riêng biệt về giải quyết các tranh chấp cũng được đề cập đến (thông qua Viện giải quyết các tranh chấp của ITLOS hoặc một trọng tài thương mại bắt buộc ${ }^{9}$ ).

Phần XII UNCLOS 1982 đề cập đến việc bảo vệ và bảo tồn môi trường biển, với những quy định về quyền và nghĩa vụ của các quốc gia và được xây dựng dựa trên các nguyên tắc phát triển của luật môi trường quốc tế được áp dụng cho các đại dương và biển. Trong khi không có quy định chi tiết về quy tắc của các nguồn gây ô nhiễm riêng lẻ, thì Phần XII cung cấp một khuôn khổ pháp lý quốc tế và luật quốc gia về việc thực thi (hợp tác trên phạm vi thế giới và khu vực; hỗ trợ kỹ thuật; giám sát liên tục và đánh giá về sinh thái; các biện pháp bảo đảm; đặc biệt tăng cường đáng kể khả năng thực thi của quốc gia có cảng $)^{10}$.

Vấn đề Nghiên cứu khoa học biển và việc phát triển, chuyển giao kỹ thuật biển cũng đã được quy định trong Phần XIII ${ }^{11}$ và Phần XIV ${ }^{12}$

\footnotetext{
${ }^{7}$ UNCLOS 1982, Phần XI, Vùng (Điều 133 - 191).

${ }^{8}$ UNCLOS 1982, Điều 136.

${ }^{9}$ UNCLOS 1982, Điều 186 và 188.

${ }^{10}$ UNCLOS 1982, Phần XII, Mục 1- 9 và 11.

${ }^{11}$ UNCLOS 1982, Phần XIII, Việc nghiên cứu khoa học biển.
}

của UNCLOS 1982. Những quy định này là những đóng góp mới của UNCLOS cho sự phát triển của luật biển quốc tế, lấp đi những khoảng trống của các điều ước quốc tế từ trước đến nay, kể cả các Công ước Geneva năm 1958 [4, tr.16]. Việc quy định về quyền và trách nhiệm của tất cả các quốc gia trong việc tiến hành nghiên cứu khoa học biển trong các vùng biển, kể cả lãnh hải, vùng tiếp giáp lãnh hải, vùng đặc quyền kinh tế và thềm lục địa trên cơ sở các nguyên tắc: nhằm mục đích hòa bình; sử dụng các phương pháp và phương tiện khoa học thích hợp; không cản trở việc sử dụng biển hợp pháp; theo đúng quy trình của UNCLOS 1982. Với những quy định tại Phần XIII, UNCLOS 1982 đã xác lập được sự cân bằng giữa lợi ích của các quốc gia ven biển và lợi ích rộng lớn hơn của cộng đồng quốc tế trong việc tự do khám phá khoa học $[4$, tr.16]. Tại Phần XIV "Phát triển và chuyển giao kỹ thuật biển"13, với 22 điều, UNCLOS 1982 điều chỉnh việc phát triển và chuyển giao công nghệ biển giữa các quốc gia là sự tiểp nối một cách logic nội dung của Phần XII, dựa trên việc tôn trọng các quyền và nghĩa vụ của các quốc gia, với sự hỗ trợ và hợp tác của các tổ chức quốc tế và Cơ quan quyền lực.

Phần XV UNCLOS $1982^{14}$ quy định về việc giải quyết các tranh chấp, là nội dung rất quan trọng, là điểm nhấn nổi trội làm nên tính đặc thù của UNCLOS 1982. Nếu cho rằng UNCLOS 1982 chứa đựng nhiều hệ thống quy phạm mới, thì Phần XV chính là một trong những chế định mới và độc đáo nhất, góp phần làm mới và bổ sung luật biển quốc tế hiện đại. Là duy nhất trong hệ thống luật pháp quốc tế vào thời điểm đó (kẻ cả cho đến nay), UNCLOS 1982 đã tạo lập một cơ chế pháp lý quốc tế với thủ tục bắt buộc để giải quyết các tranh chấp được xây dựng dựa trên khung pháp lý cơ bản về giải quyết tranh chấp một cách hòa bình được ghi nhận trong Hiến chương Liên

\footnotetext{
${ }^{12}$ UNCLOS 1982, Phần XIV, Phần XV , Phát triển và chuyển giao kỹ thuật biển.

${ }^{13}$ UNCOS 1982, Phần XIV (từ Điều 266 - 278).

${ }^{14}$ UNCLOS 1982, Phần XV, Giải quyết các tranh chấp, (Điều 217-320).
} 
hơp quốc [4, tr.16] (thương lượng, đàm phán, hòa giải, trung gian, trọng tài, tòa án). Phần XV không những chỉ ra các cơ quan giải quyết tranh chấp hiện tại như ICJ, mà còn thiết lập các cơ chế tài phán mới thông qua Toà án Quốc tế về Luật Biển (ITLOS), Tòa trọng tài được thành lập theo Phụ lục VII hoặc Tòa trọng tài đặc biệt được thành lập theo Phụ lục VIII. Đặc biệt, ITLOS là Tòa án quốc tế thường trực về luật biển giải quyết tranh chấp biển và là trung tâm của các cơ chế giải quyết các tranh chấp tại Phần XV của Công ước. Trụ sở của Tòa đặt tại Hamburg, tòa án được thành lập vào năm 1996 và đã phát triển như một thiết chế tài phán riêng biệt tham gia phân xử các tranh chấp từ nhiều lĩnh vực của luật biển, đặc biệt là liên quan đến việc phóng thích nhanh các tàu thuyền đánh cá bị bắt giữ bởi các quốc gia ven biển [5] và áp dụng các nguyên tắc môi trường vào luật biển [6].

Phần XVI của UNCLOS 1982 (Các quy định chung) đã ghi nhận các nguyên tắc thiện chí; việc sử dụng biển vào mục đích hòa bình; quyền của quốc gia trong việc cung cấp các thông tin; nghĩa vụ bảo vệ và hợp tác các hiện vật có tính chất khảo cổ hay lịch sử; trách nhiệm trong trường hợp xảy ra thiệt hại ${ }^{15}$.

Phần XVII (Các quy định cuối cùng) quy định các thủ tục về ký kết, phê chuẩn, tham gia, việc sửa đổi UNCLOS 1982; việc từ bỏ UNCLOS $1982^{16}$ cũng như quy chế của các Phụ

\footnotetext{
${ }^{15}$ UNCLOS 1982, Phần XVI, Các quy định chung, Điều 300 - 304.

${ }^{16}$ Mỗi quốc gia thành viên có thể từ bỏ Công ước bằng thông báo gửi Tổng thư ký Liên hợp quốc. Việc từ bỏ có hiệu lực sau một năm kể từ ngày nhận được thông báo, trừ khi trong thông báo nêu thời hạn chậm hơn (Điều 317). Sau mỗi giai đoạn 10 năm kể từ ngày Công ước có hiệu lực (1994), mọi quốc gia thành viên có thể gửi yêu cầu sửa đồi lên Tổng thư ký Liên hợp quốc (nội dung sửa đổi không liên quan đến hoạt động tại Vùng), Tổng thư ký gửi cho các quốc gia thành viênkhác cho ý kiến trong vòng 12 tháng. Nếu ít nhất một nửa số thành viên trả lời đồng ý, Tổng thư ký sẽ triệu tập hội nghị để thỏa thuận và/hoặc bỏ phiếu thông qua (Điều 312). Đối với yêu cầu sửa đổi bằng thủ tục đơn giản hóa, nếu trong 12 tháng có một quốc gia phản đối, thì
}

lục. Đặc biệt, tại Phần này, UNCLOS 1982 quy định nguyên tắc không chấp nhận bảo lưu, ngoại trừ các ngoại lệ đã được Công ước cho phép rõ ràng. Đồng thời, Công ước ngăn cấm các quốc gia thành viên ban hành các văn bản quy phạm nhằm loại trừ hay sửa đổi hiệu lực cuả Công ước trong khi áp dụng Công ước ở quốc gia mình ${ }^{17}$.

Công ước cũng bao gồm chín Phụ lục bổ sung. Những phụ lục này giải quyết các vấn đề khác nhau, từ việc xác định các đàn cá di cư với tần suất cao (Phụ lục I); Ủy ban ranh giơi ngoài thềm lục địa (Phụ lục II); Các quy định cơ bản điều chỉnh việc thăm dò, khảo sát và khai thác (Phụ lục III); Quy chế của xí nghiệp (Phụ lục IV); việc hòa giải (Phụ lục V); Quy chế của ITLOS (Phụ lục VI); Trọng tài (Phụ lục VII); Trọng tài đặc biệt (Phụ lục VIII) và Sự tham gia của các tổ chức quốc tế (Phụ lục IX), đều chủ yếu là nhằm bổ sung cho cơ chế giải quyết tranh chấp của Phần XV.

Để góp phần thi hành một cách hiệu quả Phần XI (Vùng) của UNCLOS 1982, ngày 28/7/1994 tại kỳ họp thứ 48 Đại Hội đồng LHQ đã thông qua Hiệp định về việc thực hiện Phần XI UNCLOS 1982. Hiệp định có hiệu lực tạm thời kể từ ngày 16/11/1994 (khoản 1 Điều 7 Hiệp định) và có hiệu lực chính thức vào ngày 28/7/1996 (khoản 1 Điều 6 Hiệp định). Hiệp định gồm 10 điều và 09 mục ở phần phụ lục, mục đích chính nhằm bổ sung thêm quy định của UNCLOS 1982 về một số nội dung: Chi phí của các quốc gia thành viên và những dàn xếp về tổ chức của Cơ quan quyền lực quốc tế về đáy biển; các xí nghiệp khai thác đáy đại dương; việc ra quyết định của Cơ quan quyền lực quốc tế về đáy biển; hội nghị xét duyệt lại các quy định về đáy biển của luật biển quốc tế; chuyển giao công nghệ; chính sách sản xuất; sự trợ giúp kinh tế; các điều khoản tài chính của hợp đồng; Ủy ban Tài chính. Các điều khoản của Hiệp định này và Phần XI UNCLOS 1982 được cùng giải thích và áp dụng như một văn

yêu cầu sửa đổi sẽ bị bác bỏ. Nếu không có quốc gia nào phản đối thì đề xuất sửa đổi coi như được chấp thuận (Điều 313).

${ }^{17}$ UNCLOS 1982, Phần XVII, Điều 309, 310. 
bản thống nhất. Trong trường hợp có sự mâu thuẫn giữa Hiệp định và Phần XI UNCLOS 1982 thì các điều khoản của Hiệp định này chiếm ưu thế (khoản 1 Điều 2 Hiệp định). Các thành viên của UNCLOS 1982 không đương nhiên trở thành thành viên của Hiệp định này mà phải trải qua một quá trình ký kêt/ gia nhập riêng biệt. Việt Nam đã gia nhập Hiệp định vào ngày $27 / 4 / 2006$. Tính đển hết năm 2020 , Hiệp định có 150 thành viên [7].

Nhằm hoàn thiện một nguyên tắc chủ yếu còn thiếu trong khuôn khổ các công cụ của UNCLOS 1982, năm 1995 một thỏa thuận bổ sung đã được đàm phán để bổ sung các quy định của Công ước liên quan đến các đàn cá nằm rải rác và di cư với tần suất cao: Hiệp định về đàn cá di cư của Liên hợp quốc năm 1995. Hiệp định được thông qua tại kỳ hợp thứ sáu của Đại Hội đồng Liên hợp quốc vào ngày 04/8/1995, và có hiệu lực từ ngày $11 / 12 / 2001$ (khoản 1 Điều 40 Hiệp định) và tính đến hết năm 2020 có 91 quốc gia thành viên [8], bao gồm cả liên minh Châu Âu. Các thành viên mới nhất tham gia Hiệp định là Việt Nam (18/12/2018), Campuchia (06/03/2020). Hiệp định đưa ra chế độ pháp lý cho việc bảo vệ và quản lý các đàn cá di cư gần và di cư xa, với mong muốn nhằm đảm bảo bảo tồn và sử dụng bền vững lâu dài những nguồn lợi này. Những đàn cá di cư xa như cá ngừ, cá kiếm, cá nhám đại dương, thường di cư với khoảng cách xa từ khu vực biển sâu đến các vùng lãnh hải của các quốc gia. Những đàn cá di cư gần như cá tuyết, cá bơn, cá thu, mực ống xuất hiện cả ở vùng đặc quyền kinh tế biển và vùng tiếp giáp với vùng biển sâu. Theo như Hiệp định này, việc bảo tồn và quản lý các đàn cá di cư phải dựa trên tiếp cận cẩn trọng và sự sẵn có cơ sở khoa học. Hiệp định cũng rất chú trọng đến các nguyên tắc cơ bản được thiết lập trong Công ước về Luật biển rằng các quốc gia nên hợp tác trong việc thực hiện các biện pháp cần thiết cho việc bảo tồn những nguồn lợi này. Trong khuôn khổ Hiệp định này, các cơ quan quản lý nghề cá cấp khu vực là những phương tiện đi đầu cho việc hợp tác giữa các quốc gia ven biển và các quốc gia khai thác vùng biển sâu trong việc bảo tồn và quản lý các đàn cá di cư nói trên. Hiệp định cũng đưa ra các nguyên tắc, thuật ngữ và quy định mới, tạo thành sự phát triển mạnh mẽ của các điều khoản liên quan đến bảo tồn và nhằm giải quyết các thách thức ảnh hưởng đến vùng biển sâu. Các biện pháp bảo tồn và quản lý đã được thông qua cho các vùng thuộc lãnh hải quốc gia và thiết lập ở vùng biển sâu yêu cầu phải có sự tương thích với nhau. Bên cạnh đó, các cơ chế cũng đã được đưa ra cho việc tuân thủ và thực thi các quy định về bảo tồn và quản lý đàn cá di cư ở vùng biển sâu. Hiệp định đã nhận rõ những yêu cầu đặc biệt của các nước thành viên đang phát triển, bao gồm việc phát triển nghề cá của chính họ và sự tham gia của họ đối với Hiệp định đàn cá di cư và quy định về sự hỗ trợ đối với các nước đang phát triển tại Phần VII của Hiệp định [9].

\section{Những thách thức}

Luật biển quốc tế đang ở trong trạng thái phát triển liên tục dựa trên sự phát triển của hoạt động thực tiễn của các quốc gia, hoạt động nghiên cứu và lập pháp trong nước (thông qua việc ban hành các đạo luật trong nước) và quốc tế (thông qua việc ký kết các điều ước quốc tế mới). Khi pháp luật đang ngày càng trở thành công cụ hiệu quả hỗ trợ loài người kiểm soát tốt hơn các vùng biển và đại dương, khi những thách thức về môi trường, biến đồi khí hậu và những thách thức địa chính trị mới được ngày một gia tăng với cường độ khó kiểm soát, càng nổi lên nhu cầu cấp thiết rằng luật biển cần phải đáp ứng với sự phát triển của loài người để đảm thực sự là công cụ, là bà đỡ cho nhân loại trong việc khai thác, bảo vệ, sử dụng và quản lý các vùng biển và đại dương.

\subsection{Biến đổi khi hậu}

Trong tất cả những thách thức hiện nay của thế kỷ 21 , tác động của biến đổi khí hậu và hiện tượng liên quan đến quá trình axit hóa đại dương được chứng minh là quan trọng nhất [10]. Tác động của biến đổi khí hậu đối với đại dương của thế giới bao gồm việc mực nước biển dâng, những thay đổi về nhiệt độ bề mặt biển, xói lở bờ biển, axit hóa đại dương và tần 
suất ngày càng tăng cao của sự kiện thời tiết khắc nghiệt, dẫn đến thay đổi tập tính di cư của rất nhiều đàn cá [11].

Mực nước biển dâng cao sẽ tạo ra những thách thức đối với các đường cơ sở trong lãnh hải đã được tuyên bố, bao gồm cả sự phụ thuộc vào các bãi cạn lúc nổi lúc chìm và rạn đá như các điểm trên đường cơ sở [11]. Hậu quả của các khả năng sửa đồi đường cơ sở do biến đổi khí hậu là đáng kể đối với hoạt động hàng hải, vì nó có thể dẫn đến quyền tiếp cận lớn hơn của các tàu nước ngoài đối với các vùng nước ven biển. Các đường cơ sở đó có thể cần phải được đo đạc lại do mực nước biển dâng cũng sẽ dẫn đến sự không chắc chắn chung về các giới hạn bên ngoài của các khu vực hàng hải đã được tuyên bố và đây có thể là nguyên nhân làm gia tăng căng thẳng đối với các khu vực tranh chấp như ở Biển Đông. Các nguy cơ hàng hải tiềm tàng cũng có thể tăng lên, đặc biệt là do băng tan trên biển với các hậu quả là những tảng băng trôi, hơn nữa đó còn là kết quả của các cơn bão cường độ mạnh và sự thay đổi hướng gió trong khu vực và các dòng biển. Những thay đổi lớn trong môi trường sống của một số nguồn tài nguyên sinh vật biển đã được xác định, kéo theo kết quả là các chế độ tài phán được đã được đưa ra để điều chỉnh một số đàn cá nhất định cần được xem xét lại. Ví dụ, sẽ cần phải điều chỉnh các hiệp định nghề cá hiện có và đàm phán các thỏa thuận mới để phản ánh sự thay đổi phạm vi của một số đàn cá nằm rải rác và các loài di cư ở mức độ cao [12].

\subsection{An ninh môi trường biển}

Tác động của biến đổi khí hậu làm cho an ninh môi trường biển sẽ trở thành một vấn đề bức xúc hơn nữa. Một trong những ví dụ đầu tiên về vấn đề này là thách thức của Australia và New Zealand năm 1973 đối với chương trình thử nghiệm vũ khí hạt nhân Thái Bình Dương của Pháp trong các vụ Thử nghiệm Hạt nhân của Pháp [13] và kéo theo việc thông qua Hiệp ước Raratonga năm $1985^{18}$ đưa ra các hạn chế

\footnotetext{
${ }^{18}$ Hiệp định Khu vực Phi hạt nhân Nam Thái Bình Dương năm 1985.
}

về việc thử nghiệm và sử dụng vũ khí hạt nhân ở Nam Thái Bình Dương. Trong những năm tới, các dự đoán chỉ ra rằng vì tác động của biến đổi khí hậu trở nên phổ biến hơn và xuất hiện nhiều toan tính của một số quốc gia xây dựng các nhà máy điện hạt nhân trên biển hoặc nạo vét đáy biển với phương tiện khổng lồ (như Trung Quốc đã và đang làm, hủy hoại nghiêm trọng môi trường trên Biển Đông), thì sự đòi hỏi của cộng đồng và của các chính phủ về bảo vệ môi trường biển sẽ tiếp tục tăng lên. Tương tự như vậy, các vấn đề môi trường biển hiện nay như rác thải đại dương [14], và tác động của quá trình axit hóa đại dương làm nổi bật các vấn đề liên quan đến mối đe dọa đối với đa dạng sinh học biển, cũng như việc bảo vệ nghề cá và nuôi trồng thủy sản. Việc tiếp cận và sử dụng nguồn gen của đại dương cũng là một vấn đề đang được xem xét từ năm 2007, khi có các vấn đề pháp lý phát sinh từ quá trình thăm dò tìm kiếm các sản phẩm sinh học mới [15], [16].

\subsection{Yêu sách về chủ quyền}

Một thách thức to lớn đối với luật biển quốc tế hiện đại là đó là xu thế tiến ra biển và yêu sách chủ quyền, quyền tài phán quốc gia. Đầu tiên là lãnh hải, tiếp đến là thềm lục địa, và sau đó trong thập niên 1960 và 1970 , một loạt các yêu sách mới đối với các vùng tiếp giáp lãnh hải và các vùng đặc quyền kinh tế, luật biển đã chứng kiến sự đòi hỏi quyền lợi ngày càng mở rộng của các quốc gia ven biển đối với các vùng biển. Mặc dù tính hợp pháp của tất cả các khu vực biển này đã được UNCLOS 1982 xác nhận, tuy nhiên vẫn còn có các khả năng để quốc gia ven biển đưa ra các yêu sách đơn phương về chủ quyền đối với một số khu vực có tác động lớn đến quyền và lợi ích của các nước trong khu vực, thậm chí ảnh hưởng đến quyền lợi của hầu hết các quốc gia khác, như yêu sách đường lưỡi bò phi lý của Trung Quốc trên Biển Đông. Tác động của việc leo thang thẩm quyền không bị kiềm chế hoặc sự bành trướng trên biển diễn ra ngày một sâu sắc, đặc biệt dẫn đến nguy cơ tiềm tàng đối với chủ quyền quốc gia, quyền tự do hàng hải, đánh bắt các và nghiên cứu khoa học biển [17], đe dọa hòa bình và an ninh quốc 
tế. Có thể kể đến hai nguyên nhân cơ bản: Thứ nhất là khả năng của các quốc gia ven biển đơn phương giải thích các điều khoản của UNCLOS 1982 để đạt được càng nhiều yêu sách biển càng tốt. Điều này có thể áp dụng đối với việc vẽ các đường cơ sở (cả đảo và quần đảo), xác nhận các khu vực biển từ các đảo cho tới các đảo đá, và việc công bố các thềm lục địa ngoài cùng. Thứ hai là khả năng áp dụng các cách giải thích đơn phương về UNCLOS 1982 của các quốc gia ven biển nhằm khẳng định các yêu sách mở rộng hơn về các quyền hoặc quyền tài phán so với những quy định của UNCLOS 1982. Mặc dù các yêu sách đơn phương trong khuôn khổ của UNCLOS 1982 có một ý nghĩa nhất định trong việc thúc đẩy sự phát triển tiến bộ của luật biển quốc tế hiện đại. Tuy nhiên, việc chủ động khẳng định các quyền chủ quyền và quyền tài phán mới trên biển, cố tình giải thích và áp dụng sai Công ước, thậm chí đưa ra những khái niệm mập mờ ("vùng nước danh nghĩa lịch sử", "vùng nước kề cận”, "quyền lịch sử",...) hiện tại, gây ra nhiều tranh cãi, nổi bật là những căng thẳng đang diễn ra ở Biển Đông giữa nhiều quốc gia khác nhau là kết quả của yêu sách chủ quyền quá mức và tranh chấp trên các đảo [18].

\section{Xem xét và hoàn thiện UNCLOS 1982}

Gần 40 năm qua, kể từ khi ra đời (năm 1982), cho đến nay, mặc dù UNCLOS - điều ước quốc tế đồ sộ nhất về biển của nhân loại, với hệ thống các hiệp định hỗ trợ (năm 1994, 1995) đã tạo lập một khung pháp lý quốc tế mang tính toàn diện, bao trùm: xác định rõ các vùng biển và đại dương cũng như đáy đại dương; điều chỉnh các hoạt động của các chủ thể trong việc khai thác, sử dụng và quản lý biển và đại dương với một hệ thống quy phạm về mặt luật nội dung và luật tố tụng..., về cơ bản, đã làm tròn sứ mệnh to lớn, góp phần quan trọng làm nên sức sống mãnh liệt, hiệu lực và hiệu quả của Luật pháp quốc tế. Tuy nhiên, những phát triển công nghệ và thách thức môi trường, $x u$ thế và tham vọng vươn ra biển của thế giới, nhất là của một số quốc gia đã và đang thực hiện chính sách cường quyền trên biển, như Trung Quốc, có cần thiết cho một Hội nghị của Liên hợp quốc lần thứ IV về Luật Biển hay không, và UNCLOS 1982 có thể tiếp tục đóng vai trò như một 'hiến pháp của biển và đại dương' không? [19]

Như đã nêu ở trên, để UNCLOS 1982 tiếp tục đóng vai trò là "hiến pháp về biển và đại dương của nhân loại”, là chế định trụ cột của Luật Biển Quốc tế và hệ thống Luật Quốc tế hiện đại, làm nòng cốt cho việc giải quyết thỏa đáng các thách thức tiềm tàng đã và sẽ tiếp tục xảy ra trên biển và đại dương... cần thiết tiếp tục xem xét, sửa đổi, bổ sung những khuyết thiếu hiện tồn của UNCLOS 1982. Có thể nêu lên một số những nội dung cấp bách cần chỉnh sửa của UNCLOS 1982 như sau:

Thí nhất, cần làm rõ Điều 7(3) UNCLOS 1982. Theo Điều 7(3) UNCLOS 1982, việc sử dụng đảo làm điểm cơ sở của đường cơ sở thẳng không được làm cho tuyến đường cơ sở đi chệch quá xa xu hướng chung của bờ biển và vùng biển ở phía bên trong đường cơ sở này phải gắn với đất liền đủ đến mức được đặt dưới chế độ nội thủy. Điều này có nghĩa là, góc lệch giữa đọạn đường cơ sở thẳng với bờ biển không được quá lớn và các đảo được sử dụng làm điểm cơ sở không được nằm quá xa bờ biển. Tuy nhiên, UNCLOS 1982 lại không có bất cứ điều khoản nào quy định cụ thể về các điều kiện này ${ }^{19}[20],[21]$.

Thú hai, cần có sự giải thích chính xác và quy định cụ thể hơn Điều 76 khoản 1 và 3 liên quan đến các khái niệm: "dốc lục địa", "bờ lục địa", "mép ngoài rìa lục địa", "việc kéo dài tự nhiên của lãnh thổ đất liền”. Việc không rõ ràng về các quy định trên sẽ khiến cho các chuyên gia pháp lý, kể cả chuyên gia về địa chất và cả

\footnotetext{
19 Theo khuyến nghị của ILC, góc lệch lớn nhất giữa đoạn đường cơ sở thẳng và bờ biển không lớn hơn $20^{\circ}$; chuỗi đảo phải được cấu thành từ ba đảo trở lên và: i) khoảng cách của mỗi đảo trong chuỗi so với đường bờ biển và giữa đảo này so với đảo kia trong chuỗi đảo đều không được vượt quá 24 hải lý; ii) chiều dài của đoạn đường cơ sở thẳng không nên quá 60 hải lý và; iii) chuỗi đảo phải chắn ít nhất $50 \%$ đường bờ biển liên quan.
} 
Ủy ban ranh giới ngoài thềm lục địa (CLCS) gặp khó khăn cũng như có thể mắc sai lầm trong việc giải thích và áp dụng Điều 76 khi đưa ra các khuyến nghị của mình [22]. Bên cạnh đó, để góp phần đảm bảo thực thi hiệu quả Điều 76, UNCLOS 1982 cần được sửa đồi theo hướng bổ sung thẩm quyền cho CLCS để cơ quan này có đủ tư cách pháp lý tham gia vào các thủ tục giải quyết tranh chấp bắt buộc cũng như có thẩm quyền đề nghị ITLOS đưa ra các ý kiến tư vấn trong trường hợp có bất đồng giữa CLCS và quốc gia ven biển trong việc giải thích và áp dụng Điều 76 [22].

Thứ ba, cần tiếp tục làm rõ các quy định tại Điều 74 và Điều 83. UNCLOS 1982, tại Khoản 1 Điều 83 cũng như Khoản 1 Điều 74, đã ghi nhận nguyên tắc công bằng trong việc phân định EEZ và thềm lục địa. Tuy nhiên, UNCLOS 1982 đã không đưa ra bất kỳ sự giải thích hay các quy tắc, tiêu chí cụ thể nào để thực hiện nguyên tắc này, do vậy nguyên tắc công bằng chủ yếu đã được xác định và giải thích bởi các thiết chế tài phán quốc tế trong các vụ việc phân định biển [22]. Các phán quyết trong giai đoạn này đã nhấn mạnh nguyên tắc công bằng "như những nguyên tắc pháp luật thực định" nhưng lại dựa trên "những khái niệm rất chung chung về công lý" [23] - nội dung cụ thể của nguyên tắc công bằng là gì và được áp dụng như thế nào đều không được giải thích rõ; mà điều này lại rất cần thiết cho việc áp dụng một nguyên tắc của luật. Do đó, UNCLOS 1982 cần được bổ sung theo hướng pháp điển hóa quy tắc "công bằng có điều chỉnh" bằng việc áp dụng phương pháp "cách đều - hoàn cảnh liên quan" trong việc phân định EEZ và thềm lục địa [22].

Thư $t u$, cần chính thức làm rõ Điều 121 về chế độ các đảo. Có thể nói, Điều 121 (3) UNCLOS 1982 đã đặt ra các điều kiện để đảo có được địa vị pháp lý ngang bằng với đất liền. Tuy nhiên, ngôn từ hết sức mập mờ của điều khoản này (cho thấy phạm vi và độ sâu của các bất đồng trong quá trình đàm phán UNCLOS 1982) đã làm nảy sinh vô số các cách giải thích khác nhau. Đây là một trong những điều còn có tính mơ hồ, gây nhiều tranh cãi trong lý luận cũng như trong cách thức giải thích và áp dụng khác nhau của một số quốc gia [22].

Thú $n a ̆ m$, cần xem xét lại quy định tại Khoản 1 Điều 298 của UNCLOS 1982. Với các quy định tại Điều 297 và 298 dường như đã tạo ra giới hạn đáng kể khả năng áp dụng thẩm quyền bắt buộc của các thiết chế tài phán quốc tế đối với các tranh chấp về việc hoạch định ranh giới các vùng biển; tranh chấp về các vịnh hay danh nghĩa lịch sử; các tranh chấp liên quan đến hoạt động quân sự; các tranh chấp mà Hội đồng Bảo an đang thụ lý [22]. Mặc dù những giới hạn như vậy chỉ tạo thành $5 \%$ của tất cả các tranh chấp có thể xảy ra theo UNCLOS 1982. Mặt khác, tỉ lệ $5 \%$ này lại nằm trong số những tranh chấp xảy ra thường xuyên nhất kể từ sau khi UNCLOS có hiệu lực (đặc biệt là các tranh chấp về phân định biển, trong đó có tranh chấp về phân định thềm lục địa) [22]. Tuy nhiên, từ thực tiễn tranh chấp biển trong thời gian qua, nhất là những tranh chấp về phân định biển là những tranh chấp "nguy hiểm nhất" vì "nằm ở trung tâm của chủ quyền" [22], thì với những giới hạn về thẩm quyền như quy định tại Điều 298(1), tất yếu đã hạn chế và ngăn cản các quốc gia đệ trình những vấn đề có tầm quan trọng đặc biệt cho một thiết chế tài phán quốc tế. Điềंu này, cũng đồng nghĩa với việc phần nào hạ thấp vai trò cũng như làm giảm hiệu quả và hiệu lực của UNCLOS 1982 cũng như hệ thống Luật Biển Quốc tế.

\section{Tài liệu tham khảo}

[1] Tullio Treves, Historical Dvelopment of the Law of the Sea (Donald R Rothwell, Alex G Oude Elferink Karen N Scott, Tim Stephens, The Oxford Handbook of The Law of the Sea, Oxford University Press, 2017, p.1.

[2] United Nations, Status of United Nations Convention on the Law of the Sea, Montego Bay, 10 December 1982, https://treaties.un.org/pages/ViewDetails III.aspx?src=TREATY\&mtdsg_no=XXI$6 \&$ chapter $=21 \&$ Temp $=$ mtdsg $3 \& \quad$ clang $=\_$en , updated on 31/12/2020.

[3] Công ước của Liên hợp quốc về Luật BiểnUnited National Convention on the Law of the 
Sea 1982, NXB Chính trị Quốc gia, Hà Nội, 1999, tr. 5.

[4] Donal R Rothwell and Tim Stephens, The International Law of the Sea, Oxford and Portland, Oregon, 2016.

[5] Donald R Rothwell và Tim Stephens, Illegal Southern Ocean Fishing and Prompt Release: Balancing Coastal and Flag State Rights and Interests, International and Comparative Law Quarterly, vol 53 (2004), pp.171-87.

[6] Donald R Rothwell, The International Tribunal for the Law of the Sea and Marine Environmental Protection: Expanding the Horizons of International Oceans Governance, Ocean Yearbook, vol 17 (2003), pp.26-55.

[7] United Nations, Status of Agreement relating to the implementation of Part XI of the Convention of 10 December 1982,।

https://www.un.org/Depts/los/

reference_files/chronological_lists_of_ratificatio n.htm, updated on 31/12/2020.

[8] United Nations, Status of Agreement for the Implementation of the Provisions of the United Nations Convention on the Law of the Sea of 10 December 1982 relating to the Conservation and Management of Straddling Fish Stocks and Highly Migratory Fish Stocks, New York, 4 August 1995, https://treaties.un.org/Pages/ViewDetails.aspx?sr $\mathrm{c}=$ TREATY\&mtdsg_no $=$ XXI-

$7 \&$ chapter=21\&clang=_en, updated on 31/12/2020.

[9] Bá Thông (2017), Giới thiệu về Công ước về Đàn cá di cư của Liên Hợp quốc năm 1995", Tông cục thủy sản, https://tongcucthuysan.gov.vn/tint\%E1\% BB\%A9c/-tin-v\%E1\%BA\%AFn/doctin/007994/2017-05-30/Banner\%20002, truy cập ngày 31/12/2020.

[10] J-P Gattuso, Contrasting Futures for Ocean and Society from Different Anthropogenic $\mathrm{CO}_{2}$ Emission Scenarios, Science Journal 45 (2015), p.349.

[11] T Stephens, Warming Waters and Souring Seas: Climate Change and Ocean Acidification, in: DR Rothwell, AG Oude-Elferink, KN Scott và $\mathrm{T}$ Stephens, The Oxford Handbook of the Law of the Sea, Oxford University Publishing, Oxford, 2015, p.777.

[12] Stephens, Warming Waters and Souring Seas, The Oxford Handbook of the Law of the Sea, Oxford, 2015, p. 133.
[13] Nuclear Tests (Australia v France) [1974] Hồi đáp số 253 của ICJ; Nuclear Tests (New Zealand v France) [1974] Hồi đáp số 457 của ICJ.

[14] R Rayfuse, MG Lawrence and KM Gjerde, Ocean Fertilisation and Climate Change-The Need to Regulate Emerging High Seas Uses, International Journal of Marine and Coastal Law 23 (2008), pp. 297-326.

[15] T Scovazzi, Bioprospecting on the Deep Seabed: A Legal Gap Requiring to be Filled, in: F Francioni và $\mathrm{T}$ Scovazzi (Edit), Biotechnology and International Law, Hart Publising, Oxford, 2006, pp. 81-97.

[16] S. Adelle Bonney, Bioprospecting, Scientific Research and Deep Sea Resources in Areas Beyond National Jurisdiction: A Critical Legal Analysis, New Zealand Journal of Environmental Law, vol 10 (2006), pp. 41-91.

[17] Donal R Rothwell and Tim Stephens, The International Law of the Sea, Oxford and Portland, Oregon (2016), pp. 25-27.

[18] Hayley Roberts, Responses to Sovereign Disputes in the South China Sea, International Journal of Maritime Coastal Law vol 30 (2015), pp. 199, in: Donal R Rothwell and Tim Stephens, The International Law of the Sea, Oxford and Portland, Oregon, 2016, p. 27.

[19] Tommy Koh, A Constitution for the Oceans, Jstor, p.117 (Donal R Rothwell and Tim Stephens, The International Law of the Sea, Oxford and Portland, Oregon, 2016, p. 28.

[20] UN Office for Ocean Affairs and the Law of the Sea, Baselines: An Examination of the Relevant Provisions of the United Nations Convention on the law of the Sea, Appendix I (Glossary and Technical Terms), UN Publication, Sales No. E.88.V5, New York, 1989.

[21] Lê Thị Anh Đào, Luận án Tiến sỹ luật học, Quy chế pháp lý của đảo theo quy định của Công ước luật biển năm 1982 và những vấn đề đặt ra đối với Việt Nam, Trường Đại học Luật Hà Nội, 2017, tr. 56.

[22] Nguyễn Hùng Cường, Luận án Tiến sỹ luật học, Giải quyết tranh chấp thềm lục địa trong pháp luật quốc tế, Khoa Luật ĐHQGHN, 2017, tr.102.

[23] N.M, Antunes, Towards the Conceptualisation of Maritime Delimitation: Legal and Technical Aspects of a Political Process, Publications on Ocean Development, Martinus Nijhoff Publisher, 2003. 